\title{
Isolasi dan Karakterisasi Enzim Selulase dari Keong Sawah Pila ampullaceal Menggunakan Substrat Serbuk Gergaji Kayu
}

\author{
Hasty Hamzah
}

Program Studi DIII Farmasi Politeknik Bau-bau, Sulawesi Tenggara 93724

\begin{abstract}
Abstrak
Enzim selulase adalah enzim yang berperan dalam katalisis reaksi hidrolisis selulosa menjadi glukosa. Enzim ini dapat diisolasi dari keong sawah Pila ampullacea menggunakan substrat selulosa alami dari serbuk gergaji kayu.Tujuan penelitian ini adalah mengisolasi dan menentukan kondisi optimum selulase dari keong sawah. Penelitian diawali dengan persiapan substrat serbuk gergaji dengan cara delignifikasi menggunakan $\mathrm{NaOH} 2 \%$. Selanjutnya mengisolasi enzim selulase dari hepatopankreas keong sawah melalui teknik destruksi, homogenisasi dan sentrifugasi. Penelitian dilanjutkan untuk memurnikan selulase melalui pengendapan protein selulase menggunakan amonium sulfat $\left(\mathrm{NH}_{4}\right)_{2} \mathrm{SO}_{4}$ pada berbagai tingkat kejenuhan 10\%, 20\%, 30\%, 40\%, $60 \%, 80 \%$. Pemurnian tahap berikutnya dilakukan dengan cara dialisis menggunakan membran selofan. Aktivitas selulase diperoleh dengan menghitung kadar glukosa sebagai produk hidrolisis dari substrat selulosa (serbuk gergaji) menggunakan metode Nelson-Somogy, sedangkan kadar protein ditentukan dengan metode Lowry dengan menggunakan bovine serum albumin (BSA) sebagai standar. Enzim selulase dari keong sawah mencapai aktivitas maksimum pada kondisi optimum: konsentrasi substrat (serbuk gergaji) $2 \%(\mathrm{~b} / \mathrm{v}), \mathrm{pH} \mathrm{5,8}$, suhu $40{ }^{\circ} \mathrm{C}$, konsentrasi enzim 7,2 mg/mL.
\end{abstract}

Kata Kunci: Selulase, keong sawah, Pila ampullacea, serbuk gergaji, isolasi, karakterisasi

\section{Pendahuluan}

Kemajuan bioteknologi telah meningkatkan pendayagunaan enzim selulase, baik dari diversifikasi pemanfaatannya maupun dalam skala penggunaannya. Selulase adalah kompleks enzim yang menghidrolisis secara sinergis selulosa menjadi selobiosa (disakarida), kemudian dihidrolisis lebih lanjut oleh enzim selobiase menghasilkan glukosa [1]. Selulase memainkan peranan penting dalam proses biodegradasi biomassa lignoselulosa, dimana selulosa dapat dikonversi menjadi glukosa [2], dan jika difermentasi lebih lanjut akan menghasilkan etanol, butanol, serta aseton. Produk fermentasi tersebut dapat dimanfaatkan sebagai biofuel (bahan bakar renewable), untuk mengurangi penggunaan bahan bakar fosil dan mengurangi polusi lingkungan [3]. Enzim tersebut juga telah digunakan dalam bidang produksi pangan, tekstil, asam-asam organik, etanol, kertas, penanganan limbah, dan analisis biokimia [4]. Di sisi lain, enzim selulase memiliki nilai ekonomi yang tinggi dan prospek penjualan yang cukup besar pada pasar global [5]. Besarnya potensi enzim selulase menjadikan permintaan terhadap enzim ini meningkat pesat. Oleh karena itu, para ilmuwan terus melakukan riset untuk memperoleh sumber selulase baru serta terus melakukan inovasi teknologi enzimatisnya.

Berdasarkan peran enzim selulase dalam mengkatalisis reaksi hidrolisis selulosa, maka enzim ini dapat dimanfaatkan untuk menghidrolisis selulosa yang terkandung dalam serbuk gergaji kayu (saw dust). Serbuk gergaji sebagai hasil industri pengolahan kayu merupakan limbah lignoselulosa yang mengandung 42$45 \%$ selulosa dan $27-30 \%$ hemiselulosa [6]. Tingginya kadar selulosa pada serbuk gergaji dapat dimanfaatkan sebagai salah satu sumber selulosa alamiah. Serbuk gergaji ini sangat berpotensi maksimal untuk produksi selulase secara komersial bagi semua organsime [7, 8]. Enzim selulase sekaligus berperan sebagai biokonvertor limbah selulosa (khususnya serbuk gergaji) yang cukup melimpah untuk mengatasi masalah lingkungan [9].

Enzim selulase dapat disolasi dari mikroorganisme, hewan, tumbuhan. Telah banyak dilaporkan bahwa selulase dapat diisolasi dari hewan tingkat rendah seperti moluska, antara lain keong Mudalia dilatata [10], (Farrisdkk., 1994), keong mas Pomacea canaliculata [11], bekicot Achatina fulica [12, 13], siput air tawar

*Email: hastyhamzah@gmail.com 
Ampullaria crossean [14], dan keong afrika Archatina marginata [15].

Penelitian ini bertujuan untuk mengisolasi selulase dari salah satu jenis keong lain yakni keong sawah. Genus Pila merupakan keong pemakan tumbuhan utamanya berupa daun tumbuhan air yang mengandung selulosa dan dimanfaatkan sebagai sumber energinya [16]. Proses pencernaan selulosa dalam sistem digestif (pencernaan) hewan invertebrata termasuk keong sawah merepresentasikan adanya simbiosis enzim selulase dengan bakteri atau mikroorganisme lain [17]. Mikroorganisme selulolitik memproduksi enzim selulase (secara intraseluler) untuk mencerna makanan (selulosa) yang sebagian besar disimpan dalam hepatopankreas yang bermuara ke saluran pencernaan. Hal tersebut menunjukkan bahwa enzim selulase dapat diisolasi dari keong sawah Pila ampullacea.

Selain mengisolasi enzim selulase, penelitian ini juga bertujuan untuk menentukan kondisi optimum enzim selulase (konsentrasi substrat, $\mathrm{pH}$, suhu dan konsentrasi enzim). Kondisi optimum selulase perlu diketahui agar aktivitas enzim dapat dicapai maksimal dalam menghidrolisis substrat serbuk gergaji menjadi glukosa

\section{Bahan dan Metode}

\subsection{Persiapan bahan baku dan delignifikasi}

Serbuk gergaji kayu dicuci dengan air kemudian dijemur sampai kering selanjutnya dihaluskan dengan blender kemudian diayak dengan ayakan ukuran 100 mesh. Proses delignifikasi dilakukan dengan mencampur serbuk gergaji kayu 100 mesh dengan larutan natrium hidroksida $(\mathrm{NaOH})$ untuk meningkatkan hasil hidrolisis [18]. Campuran serbuk gergaji dan larutan $\mathrm{NaOH} 2 \% \mathrm{~b} / \mathrm{v}$ dimasukkan ke dalam wadah tertutup, dipanaskan pada suhu $121{ }^{\circ} \mathrm{C}$ dan dibiarkan selama 30 menit sambil sesekali diaduk lalu disaring dengan kain penyaring. Residu dicuci dengan akuades hingga lignin yang berwarna coklat kehitaman keluar. Proses pencucian dihentikan setelah cairan pencuci sudah jernih dan $\mathrm{pH}$ netral, kemudian sampel dikeringkan dalam oven pada suhu $45^{\circ} \mathrm{C}$ hingga kering $[10,19]$. Kadar selulosa sebelum dan setelah delignifikasi ditentukan dengan metode Chesson [20].

\subsection{Isolasi dan Pemurnian Enzim Selulase}

Sebanyak $75 \mathrm{~g}$ hepatopankreas keong sawah dihomogenisasi dengan $500 \mathrm{~mL} \mathrm{NaCl} \mathrm{1 \% (pH} \mathrm{=7)}$ dingin dalam blender selama 3 menit. Homogenat yang diperoleh disaring dengan kain steril. Kemudian residu dibuang sedangkan filtratnya disentrifugasi selama 30 menit pada suhu $2-4{ }^{\circ} \mathrm{C}$ dengan kecepatan 6000 rotation per minute (rpm), supernatan yang dihasilkan merupakan enzim selulase kasar (ekstrak enzim). Ekstrak kasar selulase selanjutnya dimurnikan dengan teknik fraksinasi melalui presipitasi (pengendapan) protein enzim menggunakan garam amonium sulfat $\left(\mathrm{NH}_{4}\right)_{2} \mathrm{SO}_{4}$ pada berbagai tingkat kejenuhan $10 \%, 20 \%, 30 \%, 40 \%, 60 \%$ hingga $80 \%$. Fraksi dengan aktivitas selulase tertinggi dimurnikan lebih lanjut, dan sisa garam amonium sulfat dihilangkan melalui teknik dialisis menggunakan membran selofan dalam buffer sitrat fosfat. Selulase murni digunakan untuk karakterisasi selanjutnya.

\subsection{Uji Aktivitas Enzim dan Penentuan Kadar Protein}

Penentuan aktivitas enzim ditentukan berdasarkan jumlah glukosa yang dihasilkan selama 60 menit inkubasi dengan konsentrasi substrat serbuk kayu $2 \%$, $\mathrm{pH}$ 5,6 dan suhu $37^{\circ} \mathrm{C}$. Jumlah glukosa bebas yang dihasilkan ditentukan dengan menggunakan spektrofotometer berdasarkan metode Nelson-Somogy. Kadar protein ditentukan dengan metode Lowry, dimana larutan diukur dengan spektrofotometer spektronik 20D pada panjang gelombang maksimum, dan kadar proteinnya ditentukan berdasarkan kurva standar bovine serum albumin (BSA).

\subsection{Karakterisasi enzim selulase}

Karakterisasi dilakukan untuk menentukan kondisi optimum enzim selulase sehingga diperoleh aktivitas maksimum. Kondisi optimum meliputi penentuan konsentrasi substrat (serbuk gergaji hasil delignifikasi), $\mathrm{pH}$, suhu dan konsentrasi enzim. Pada penentuan konsentrasi substrat, substrat divariasikan $0,5 \% ; 1 \%$; $1,5 \% ; 2 \% ; 2,5 \%$ dan $3 \%$, sedangkan suhu bervariasi pada suhu $30{ }^{\circ} \mathrm{C} ; 35{ }^{\circ} \mathrm{C} ; 40{ }^{\circ} \mathrm{C} ; 45{ }^{\circ} \mathrm{C}$ dan $50{ }^{\circ} \mathrm{C}$. Pengaruh $\mathrm{pH}$ terhadap aktivitas selulase menggunakan buffer sitrat fosfat pada rentan $\mathrm{pH} 5,2 ; 5,4 ; 5,6 ; 5,8 ; 6,0 ; 6,2$ dan penentuan konsentrasi enzim dilakukan pada variasi 1,8 $\mathrm{mg} / \mathrm{mL} ; 3,6 \mathrm{mg} / \mathrm{mL} ; 5,4 \mathrm{mg} / \mathrm{mL} ; 6,0 \mathrm{mg} / \mathrm{mL} ; 7,2 \mathrm{mg} / \mathrm{mL}$; $9,0 \mathrm{mg} / \mathrm{mL} ; 10,8 \mathrm{mg} / \mathrm{mL}$.

\section{Hasil}

\subsection{Penentuan Kadar Selulosa Sebelum dan Setelah Delignifikasi}

Analisis kadar selulosa menggunakan metode Chesson menunjukan bahwa dalam substrat serbuk gergaji sebelum delignifikasi adalah 16,69\% sedangkan setelah delignifikasi meningkat sebesar $26,97 \%$ (Tabel $1)$. 
Tabel 1. Penentuan kadar selulosa serbuk gergaji sebelum dan setelah proses delignifikasi

\begin{tabular}{ccccc}
\hline $\begin{array}{l}\text { Serbuk } \\
\text { gergaji }\end{array}$ & $\begin{array}{c}\text { Berat } \\
\text { sampel } \\
(\mathrm{a})(\mathrm{g})\end{array}$ & $\begin{array}{c}\text { Berat } \\
\text { residu } \\
(\mathrm{c})(\mathrm{g})\end{array}$ & $\begin{array}{c}\text { Berat } \\
\text { residu } \\
(\mathrm{d})(\mathrm{g})\end{array}$ & $\begin{array}{c}\text { Kadar } \\
\text { selulosa }(\%)\end{array}$ \\
\hline A & 1,0017 & 0,7447 & 0,5788 & 16,6882 \\
B & 1,0014 & 0,9616 & 0,6928 & 26,9769 \\
\hline A: Tidak terlignifikasi & & & \\
B: Terlignifikasi & & &
\end{tabular}

\subsection{Isolasi dan pemurnian enzim}

Isolasi enzim yang dilakukan melalui destruksi, homogenisasi dan sentrifugasi sel hepatopankreas keong sawah menghasilkan ekstrak selulase (crude) dengan aktivitas rendah. Oleh karena itu dilakukan pemurnian dengan cara presipitasi protein enzim menggunakan amonium sulfat. Untuk mengetahui tingkat kejenuhan optimum protein enzim dilakukan fraksinasi mulai $10 \%$, $20 \%, 30 \%, 40 \%, 60 \%$ dan $80 \%$.

Tabel 2. Aktivitas tiap tingkat kejenuhan amonium sulfat

\begin{tabular}{cccc}
\hline $\begin{array}{c}\text { Fraksi } \\
(\%)\end{array}$ & $\begin{array}{c}{[\text { Glukosa }]} \\
(\mathrm{mg} / \mathrm{mL})\end{array}$ & $\begin{array}{c}\text { Aktivitas } \\
(\mathrm{U} / \mathrm{mL})\end{array}$ & $\begin{array}{c}\text { Kadar Protein } \\
(\mathrm{mg} / \mathrm{mL})\end{array}$ \\
\hline $0-10$ & 0,3073 & 0,0285 & 18,5662 \\
$0-20$ & 0,1779 & 0,0165 & 23,1252 \\
$20-30$ & 0,0226 & 0,0021 & 6,37595 \\
$20-40$ & 0,0449 & 0,0042 & 21,3413 \\
$40-60$ & 0,0166 & 0,0015 & 17,7073 \\
$60-80$ & 0,0101 & 0,0001 & 15,7251 \\
\hline
\end{tabular}

Tabel 2 menunjukkan aktivitas dan kadar protein setiap fraksi. Enzim selulase pada fraksi $10 \%$ memiliki aktivitas tertinggi $0,0285 \mathrm{U} / \mathrm{mL}$ dan kadar protein $18,5662 \mathrm{mg} / \mathrm{mL}$. Enzim pada fraksi ini, dimurnikan lebih lanjut dengan cara dialisis. Dalam setiap tahap pemurnian selulase dilakukan pengukuran kadar protein dan aktivitas spesifik selulase, sehingga dapat diketahui tingkat kemurnian pada setiap tahap pemurnian. Perbandingan aktivitas crude selulase, ditunjukkan oleh Tabel 3, dimana selulase hasil pemurnian menggunakan amonium sulfat $10 \%$ dan dialisis.
Tabel 3 menunjukkan peningkatan aktivitas enzim dan penurunan kadar protein. Aktivitas enzim ekstrak kasar adalah $0,0069 \mathrm{U} / \mathrm{mL}$ dengan kadar protein 49,6861 $\mathrm{mg} / \mathrm{mL}$, aktivitas enzim meningkat pada fraksi amonium sulfat $10 \%$ adalah $0,0229 \mathrm{U} / \mathrm{mL}$ dengan kadar protein $18,5662 \mathrm{mg} / \mathrm{mL}$, dan semakin meningkat untuk enzim hasil dialisis dengan aktivitas $0,0448 \mathrm{U} / \mathrm{mL}$ dan kadar protein semakin menurun hingga $17,5090 \mathrm{mg} / \mathrm{mL}$.

\subsection{Konsentrasi substrat optimum}

Tabel 4. Aktivitas tiap tingkat kejenuhan amonium sulfat

\begin{tabular}{cccc}
\hline $\begin{array}{c}\text { [Substrat] } \\
\%, \mathrm{~b} / \mathrm{v}\end{array}$ & Absorbansi & $\begin{array}{c}\text { Kadar glukosa } \\
(\mathrm{mg} / \mathrm{mL})^{*}\end{array}$ & $\begin{array}{c}\text { Aktivitas } \\
(\mathrm{U} / \mathrm{mL})\end{array}$ \\
\hline 0,5 & 0,404 & 0,7668 & 0,0709 \\
1,0 & 0,612 & 1,1777 & 0,1091 \\
1,5 & 0,676 & 1,3043 & 0,1208 \\
2,0 & 0,794 & 1,5380 & 0,1424 \\
2,5 & 0,788 & 1,5257 & 0,1413 \\
3,0 & 0,754 & 1,4585 & 0,1350 \\
\hline Ket: $\left.{ }^{*}\right)$ Pengenceran 20x & &
\end{tabular}

Tabel 4 memperlihatkan pengaruh peningkatan konsentrasi substrat terhadap aktivitas enzim. Aktivitas meningkat sebesar $0,0709 \mathrm{U} / \mathrm{mL}$ untuk konsentrasi $0,5 \%$ hingga $0,1424 \mathrm{U} / \mathrm{mL}$ pada konsentrasi 2\%. Pada konsentrasi 2,5\%, aktivitas enzim selulase cenderung tetap yakni $0,1413 \mathrm{U} / \mathrm{mL}$. Dapat dikatakan bahwa aktivitas maksimum dicapai pada saat konsentrasi substrat $2 \%$.

\section{4 pH Optimum}

Nilai $\mathrm{pH}$ optimum enzim selulase ditetapkan pada berbagai $\mathrm{pH}$ buffer sitrat fosfat yakni mulai $\mathrm{pH} 5,2$ hingga $\mathrm{pH}$ 6,2. Hasil penelitian yang ditunjukan pada Tabel 5, terlihat bahwa aktivitas meningkat dengan meningkatnya $\mathrm{pH}$ dari $\mathrm{pH} 5,2$ hingga $\mathrm{pH} 5,6$. Aktivitas selulase maksimum pada $\mathrm{pH} 5,8$ yaitu sebesar 0,0436 $\mathrm{U} / \mathrm{mL}$. Pada nilai $\mathrm{pH}$ yang lebih tinggi 6,0 dan $\mathrm{pH} 6,2$ aktivitas menurun tajam berturut-turut $0,0172 \mathrm{U} / \mathrm{mL}$ dan $0,0053 \mathrm{U} / \mathrm{mL}$. Dengan demikian dapat dikatakan bahwa $\mathrm{pH}$ optimum enzim selulase dari keong sawah pada substrat serbuk gergaji kayu adalah 5,8.

Tabel 3. Aktivitas dan kadar protein setiap tahap pemurnian

\begin{tabular}{lccccc}
\hline \multicolumn{1}{c}{ Fraksi Enzim } & $\begin{array}{c}\text { Kadar Glukosa } \\
(\mathrm{mg} / \mathrm{mL})\end{array}$ & $\begin{array}{c}\text { Aktivitas } \\
(\mathrm{U} / \mathrm{mL})\end{array}$ & $\begin{array}{c}\text { Kadar Protein } \\
(\mathrm{mg} / \mathrm{mL})\end{array}$ & $\begin{array}{c}\text { Aktivitas Spesifik } \\
(\mathrm{U} / \mathrm{mg})\end{array}$ & $\begin{array}{c}\text { Tingkat } \\
\text { Kemurnian }\end{array}$ \\
\hline Ekstrak kasar & 0,0751 & 0,0069 & 49,6861 & 0,00014 & 1 \\
Fraksinasi 0-10\% & 0,2470 & 0,0229 & 18,5662 & 0,00123 & 8,803 \\
Dialisis & 0,4842 & 0,0448 & 17,5090 & 0,00256 & 18,296 \\
\hline
\end{tabular}


Tabel 5. Pengaruh $\mathrm{pH}$ terhadap aktivitas enzim

\begin{tabular}{cccc}
\hline $\mathrm{pH}$ & Absorbansi & $\begin{array}{c}\text { Kadar glukosa } \\
(\mathrm{mg} / \mathrm{mL})^{*}\end{array}$ & $\begin{array}{c}\text { Aktivitas } \\
(\mathrm{U} / \mathrm{mL})\end{array}$ \\
\hline 5,2 & 0,246 & 0,1136 & 0,0105 \\
5,4 & 0,440 & 0,2095 & 0,0194 \\
5,6 & 0,542 & 0,2599 & 0,0240 \\
5,8 & 0,970 & 0,4713 & 0,0436 \\
6,0 & 0,392 & 0,1858 & 0,0172 \\
6,2 & 0,131 & 0,0568 & 0,0053 \\
\hline
\end{tabular}

\subsection{Sиhи Optimum}

Tabel 6 menggambarkan bahwa suhu berpengaruh secara signifikan terhadap aktivitas enzim selulase. Diketahui terjadi peningkatan aktivitas enzim selulase dari suhu dari $30{ }^{\circ} \mathrm{C}$ hingga suhu $40^{\circ} \mathrm{C}$. Pada suhu $30^{\circ} \mathrm{C}$ aktivitas enzim selulase adalah sebesar $0,02 \mathrm{U} / \mathrm{mL}$ dan meningkat hingga $0,0472 \mathrm{U} / \mathrm{mL}$ pada suhu $40{ }^{\circ} \mathrm{C}$ dan kemudian menurun hingga $0,0269 \mathrm{U} / \mathrm{mL}$ pada suhu 50 ${ }^{\circ} \mathrm{C}$. Dari data tersebut menunjukan bahwa aktivitas optimum enzim dicapai pada suhu $40{ }^{\circ} \mathrm{C}$ dengan aktivitas $0,0472 \mathrm{U} / \mathrm{mL}(0,0472 \mu \mathrm{mol}$ glukosa/ $\mathrm{mL}$ per menit).

Tabel 5. Pengaruh $\mathrm{pH}$ terhadap aktivitas enzim

\begin{tabular}{cccc}
\hline Suhu $\left({ }^{\circ} \mathrm{C}\right)$ & Absorbansi & $\begin{array}{c}\text { Kadar Glukosa } \\
(\mathrm{mg} / \mathrm{mL})^{*}\end{array}$ & $\begin{array}{c}\text { Aktivitas } \\
(\mathrm{U} / \mathrm{mL})\end{array}$ \\
\hline 30 & 0,235 & 0,2164 & 0,02 \\
35 & 0,27 & 0,2509 & 0,0232 \\
40 & 0,532 & 0,5098 & 0,0472 \\
45 & 0,376 & 0,3557 & 0,0329 \\
50 & 0,311 & 0,2915 & 0,0269 \\
\hline
\end{tabular}

Ket: *) Pengenceran 5x

\subsection{Konsentrasi Enzim Optimum}

Tabel 7 menunjukan pengaruh konsentrasi enzim terhadap aktivitas selulase. Terlihat bahwa aktivitas enzim mulai konsentrasi $1,8 \mathrm{mg} / \mathrm{mL}$ masih cukup rendah sebesar $0,0033 \mathrm{U} / \mathrm{mL}$. Aktivitas enzim semakin meningkat pada konsentrasi $3,6 \mathrm{mg} / \mathrm{mL}$ dengan aktivitas sebesar $0,0154 \mathrm{U} / \mathrm{mL}$ hingga $0,0608 \mathrm{U} / \mathrm{mL}$ pada konsentrasi $6 \mathrm{mg} / \mathrm{mL}$. Pada kondisi ini konsentrasi enzim makin tinggi, sisi aktif enzim makin banyak mengikat substrat. Selanjutnya kenaikan konsentrasi enzim sampai $7,2 \mathrm{mg} / \mathrm{mL}$ menyebabkan aktivitas enzim meningkat menjadi 0,0977 U/mL. Penambahan enzim di atas konsentrasi tersebut tidak merubah aktivitas enzim secara signifikan walaupun terjadi sedikit penurunan maupun peningkatan aktivitas pada konsentrasi enzim 9 $\mathrm{mg} / \mathrm{mL}$ dan $10,8 \mathrm{mg} / \mathrm{mL}$. Hal ini mengindikasikan bahwa pada konsentrasi enzim $7,2 \mathrm{mg} / \mathrm{mL}$ aktivitas mencapai maksimum.
Tabel 7. Aktivitas Enzim terhadap variasi konsentrasi enzim

\begin{tabular}{cccc}
\hline $\begin{array}{c}\text { Konsentrasi } \\
(\mathrm{mg} / \mathrm{mL})\end{array}$ & Absorbansi & $\begin{array}{c}\text { Kadar } \\
\text { Glukosa } \\
(\mathrm{mg} / \mathrm{mL})\end{array}$ & $\begin{array}{c}\text { Aktivitas } \\
(\mathrm{U} / \mathrm{mL})\end{array}$ \\
\hline 1,8 & 0,088 & $0,0356^{*}$ & 0,0033 \\
3,6 & 0,100 & $0,1660^{* *}$ & 0,0154 \\
5,4 & 0,336 & $0,6324^{* *}$ & 0,0586 \\
6,0 & 0,348 & $0,6561^{* *}$ & 0,0608 \\
$\mathbf{7 , 2}$ & $\mathbf{0 , 5 5}$ & $\mathbf{1 , 0 4 3 5}^{* *}$ & $\mathbf{0 , 0 9 7 7}$ \\
9,0 & 0,54 & $1,0356^{* *}$ & 0,0959 \\
& 0,543 & $1,0553^{* *}$ & 0,0966 \\
\hline Ket: & $\left.{ }^{*}\right)$ Pengenceran 5x & & \\
& $* *)$ Pengenceran 20x & &
\end{tabular}

\section{Pembahasan}

Bahan lignoselulosa sangat besar peranannya sebagai substrat enzim selulase dalam biokonversi selulosa menghasilkan glukosa. Serbuk gergaji kayu merupakan bahan lignoselulosa yang memiliki kandungan selulosa dan lignin yang besar. Untuk meningkatkan proses hidrolisis secara enzimatik maka perlu dilakukan perlakuan awal yang disebut proses delignifikasi dengan menggunakan bantuan senyawa katalis, salah satu caranya adalah dengan menggunakan katalis kimia berupa senyawa $\mathrm{NaOH}[21,22]$. Berdasarkan Tabel 1, serbuk gergaji yang telah melalui proses delignifikasi dengan $\mathrm{NaOH}$ memiliki kadar selulosa yang lebih tinggi. Hal ini terjadi karena banyaknya lignin yang hilang akibat terdegradasi oleh $\mathrm{NaOH}$ yang menyebabkan pula terjadinya safonifikasi ikatan ester dari residu lignin dan hemiselulosa menjadi lebih terbuka sehingga struktur selulosa lebih mudah untuk dihidrolisis oleh enzim dan menghasilkan glukosa yang maksimal.

Enzim selulase merupakan enzim ekstraselular yang diproduksi di dalam sel mikroba selulolitik dan kemudian dikeluarkan dari sel masuk ke dalam sistem pencernaan untuk mencerna selulosa. Proses isolasi selulase dari hepatopankreas melalui tahapan dekstruksi sel yaitu pelepasan enzim dari matriks sel. Enzim selulase dipisahkan dari matriks sel dengan cara merusak membran sel melalui pengaturan tekanan osmosis larutan diluar sel dengan menggunakan larutan $\mathrm{NaCl}$ dan homogenisasi dengan menggunakan blender. Selanjutnya homogenat disentrifugasi menghasilkan endapan dan supernatan. Endapan yang diperoleh dilarutkan dalam buffer sitrat fosfat $\mathrm{pH} 5,6$. Hasil isolasi ini merupakan selulase kasar dengan aktivitas 0,0069 $\mathrm{U} / \mathrm{mL}$.

Pemurnian melalui fraksinasi dengan $\left(\mathrm{NH}_{4}\right)_{2} \mathrm{SO}_{4}$ dilakukan untuk meningkatkan aktivitas enzim pada tingkat kejenuhan $0-10 \%, 0-20 \%, 20-30 \%, 20-40 \%, 40-$ $60 \%$, dan $60-80 \%$ (Tabel 2). Penambahan garam netral $(\mathrm{NH} 4)_{2} \mathrm{SO}_{4}$ ke dalam larutan enzim pada tingkat 
kejenuhan yang optimum akan meningkatkan muatan listrik di sekitar protein enzim, yang akan menarik mantel air dari molekul protein. Interaksi hidrofobik di antara sesama molekul protein pada suasana ionik tinggi akan menurunkan kelarutan protein, sehingga protein enzim mengendap. Enzim selulase yang diperoleh dari hasil presipitasi dengan $\left(\mathrm{NH}_{4}\right)_{2} \mathrm{SO}_{4} \quad 10 \%$ masih belum murni karena mengandung sisa-sisa garam $\left(\mathrm{NH}_{4}\right)_{2} \mathrm{SO}_{4}$ sehingga perlu dilakukan cara dialisis. Batas akhir dialisis ditandai dengan tidak adanya endapan $\mathrm{BaSO}_{4}$ ketika larutan buffer ditambahkan garam $\mathrm{BaCl}_{2}$. Lamanya waktu dialisis yang diperlukan adalah 9 jam. Setiap tahap pemurnian enzim selulase dilakukan pengukuran kadar protein dan aktivitas spesifik, sehingga dapat diketahui tingkat kemurnian pada setiap tahap pemurnian.

Tabel 3 menunjukkan bahwa pemurnian dengan $\left(\mathrm{NH}_{4}\right)_{2} \mathrm{SO}_{4} 10 \%$ menghasilkan aktivitas spesifik selulase $0.00123 \mathrm{U} / \mathrm{mg}$ dengan tingkat kemurnian 8,803. Nilai ini meningkat dibandingkan aktivitas spesifik selulase kasar $(0,00014 \mathrm{U} / \mathrm{mg})$. Teknik dialisis dapat memisahkan molekul yang berukuran kecil (garam amonium sulfat) dari molekul yang berukuran besar yakni molekul enzim selulase melalui membran selofan. Hal ini ditandai dengan meningkatnya aktivitas spesifik selulase yaitu 0,00256 U/mg dengan tingkat kemurnian 18,296.

Aktivitas enzim meningkat sebesar $0,0709 \mathrm{U} / \mathrm{mL}$ untuk konsentrasi $0,5 \%$ hingga $0,1424 \mathrm{U} / \mathrm{mL}$ untuk konsentrasi $2 \%$ pada uji atau penentuan konsentrasi substrat (Tabel 4). Aktivitas enzim cenderung tetap pada konsentrasi $2,5 \%$ yakni $0,1413 \mathrm{U} / \mathrm{mL}$. Hal ini disebabkan terjadinya kejenuhan dimana sisi aktif enzim selulase telah dipenuhi oleh substrat. Tingginya konsentrasi substrat tidak menyebabkan bertambahnya konsentrasi kompleks enzim substrat, bahkan penambahan konsentrasi substrat lebih lanjut justru menghambat kerja enzim karena substrat yang semakin banyak akan berdesakan satu sama lain berikatan dengan sisi aktif enzim. Akibatnya, stabilitas kompleks enzim substrat akan terganggu.

Enzim memiliki $\mathrm{pH}$ optimum yang khas, yaitu $\mathrm{pH}$ yang dapat menghasilkan aktivitas maksimum dalam mengkatalisis suatu reaksi. Perubahan $\mathrm{pH}$ berpengaruh terhadap aktivitas enzim melalui perubahan struktur atau muatan residu asam amino yang berfungsi dalam pengikatan substrat. $\mathrm{pH}$ yang bervariasi juga dapat menyebabkan perubahan konformasi enzim. Hal ini terjadi karena gugus bermuatan yakni $-\mathrm{NH}_{3}{ }^{+}$atau $-\mathrm{COO}^{-}$ yang jauh dari daerah terikatnya susbtrat yang mungkin diperlukan untuk mempertahankan struktur tersier akan mengalami perubahan muatan pada $\mathrm{pH}$ yang berbeda. Hal ini menyebabkan terganggunya ikatan ionik dan terputusnya ikatan enzim dengan substrat (folding) sehingga konformasi enzim berubah. Perubahan inilah yang menyebabkan aktivitas enzim menurun. $\mathrm{pH}$ optimum selulase dalam penelitian ini berada pada kisaran $\mathrm{pH}$ optimum dari beberapa penelitian sebelumnya. Li et al (2009) meneliti selulase dari lambung siput Ampullariacrossean pada $\mathrm{pH}$ optimum berkisar 5,5-6,5 [14].

Perubahan suhu terhadap aktivitas enzim memberikan pengaruh signifikan. Reaksi enzimatis berlangsung paling cepat pada suhu optimum karena aktivitas enzim titik maksimum. Peningkatan suhu dari $30^{\circ} \mathrm{C}$ hingga $35^{\circ} \mathrm{C}$ menyebabkan aktivitas enzim meningkat. Kenaikan suhu optimum pada suhu $40^{\circ} \mathrm{C}$ menyebabkan peningkatan energi kinetik sehingga menambah intensitas tumbukan antara substrat dengan enzim dan produk yang terbentuk lebih maksimal. Di atas suhu optimum, enzim akan mengalami denaturasi dan kehilangan aktivitas katalitiknya (inaktivasi), ditunjukan dengan menurunnya aktivitas pada suhu $45^{\circ} \mathrm{C}$ dan $50^{\circ} \mathrm{C}$. Proses inaktivasi enzim pada temperatur yang sangat tinggi berlangsung melalui 2 tahap yaitu diawali dengan pembukaan parsial struktur sekunder, tersier, dan kuartener molekul enzim akibat putusnya ikatan-ikatan kovalen maupun ikatan hidrofobik dan selanjutnya terjadi perubahan struktur primer enzim karena adanya kerusakan asam-asam amino tertentu akibat pemanasan. Suhu optimum ini sesuai dengan penelitian mengenai enzim selulase yang diisolasi dari udang Cherax quadrinatus dan kumbang merah Tribolium castaneum [3]. Di sisi lain, penelitian lainnya menunjukkan hasil bahwa selulase (Hgcel) dari Hirondellea gigas secara efisien dapat memproduksi glukosa dari substrat kayu kering pada suhu $35^{\circ} \mathrm{C}$ [23].

Kecepatan suatu reaksi yang menggunakan enzim tergantung pada konsentrasi enzim tersebut. Pada konsentrasi substrat tertentu, kecepatan reaksi bertambah dengan bertambahnya konsentrasi enzim. Tetapi setelah mencapai aktivitas maksimumnya, maka penambahan konsentrasi enzim tidak akan mengubah aktivitas enzim. Terlihat bahwa aktivitas enzim mulai konsentrasi 1,8 $\mathrm{mg} / \mathrm{mL}$ masih cukup rendah sebesar $0,0033 \mathrm{U} / \mathrm{mL}$. Aktivitas enzim semakin meningkat pada konsentrasi 3,6 $\mathrm{mg} / \mathrm{mL}$ dengan aktivitas sebesar $0,0154 \mathrm{U} / \mathrm{mL}$ hingga $0,0608 \mathrm{U} / \mathrm{mL}$ pada konsentrasi $6 \mathrm{mg} / \mathrm{mL}$. Selanjutnya kenaikan konsentrasi enzim sampai 7,2 $\mathrm{mg} / \mathrm{mL}$ menyebabkan aktivitas enzim meningkat menjadi 0,0977 $\mathrm{U} / \mathrm{mL}$. Penambahan enzim di atas konsentrasi tersebut tidak merubah aktivitas enzim secara signifikan walaupun terjadi sedikit penurunan maupun peningkatan aktivitas pada konsentrasi enzim $9 \mathrm{mg} / \mathrm{mL}$ dan 10,8 $\mathrm{mg} / \mathrm{mL}$. Hal ini mengindikasikan bahwa pada konsentrasi enzim 7,2 $\mathrm{mg} / \mathrm{mL}$ aktivitas mencapai maksimum. Pada konsentrasi enzim optimum ini, seluruh bagian active site dari enzim berikatan dengan substrat membentuk kompleks enzim substrat. 
Konsentrasi enzim optimum yang diperoleh pada peneitian ini tidak jauh berbeda dengan konsentrasi enzim optimum pada penelitian sebelumnya, yakni $5,0076 \mathrm{mg} / \mathrm{mL}[24]$.

\section{Kesimpulan}

Keong sawah memiliki potensi menghasilkan enzim selulase, melalui isolasi hepatopankreas dengan teknik destruksi, homogenisasi dan sentrifugasi. Aktivitas enzim selulase yang diperoleh meningkat pada kondisi optimum yakni pada konsentrasi substrat serbuk gergaji $2 \%(\mathrm{~b} / \mathrm{v}), \mathrm{pH} 5,8$, suhu $40{ }^{\circ} \mathrm{C}$, dan konsentrasi enzim 7,2 $\mathrm{mg} / \mathrm{mL}$.

\section{Ucapan Terima Kasih}

Penulis menyampaikan terimakasih kepada Prof. Abd. Rauf Patong dan ibu Dr. Seniwati Dali, MSi yang telah memberikan pengarahan dan petunjuk dalam menyelesaikan jurnal ilmiah ini, serta kepada Dirjen DIKTI atas bantuan beasiswa selama penelitian ini.

\section{Daftar Pustaka}

1. Jyotsna KP, Vijayalakhsmi K, Prasanna ND, Shaheen SK. Isolation, Characterization of Cellulase Producing Lysinibacillus sphaericus MTCC No. 9468 from Gut of Eisenia foetida. The Bioscan, 2010, 6; 325-327.

2. Barman D, Saud ZA, Habib MR, Islam MF, Hossain K, Yeasmin T. Isolation of Cellulolytic Bacterial Strain from Effective and Efficient Bioconversion of Solid Stete. Life Sci. and Med. Res., 2011, 25.

3. Rehman FU. Isolation of Cellulolytic Activities from Tribolium castaneum (Red Flour Beetle), African J. of Biotech., 2009, 8; 6710 - 6715.

4. Peciulyte D. Isolation of Cellulolytic Fungi from Waste Paper Gradual Recycling Materials, Ekologia, 2007, 53; 11-18.

5. Ain QU, Baig S, Saleem M. Production andCharacterization of Cellulases Of Aspergillus niger by Using Rice Husk and Saw Dust as Substrates. Pak. J. Bot, 2012, 44; 377-382.

6. Iranmahboob J, Nadim JF, Monemi S. Optimizing Acidhydrolysis: a Critical Step for Production of Ethanol from Mixed Wood Chips. Biomass and Bioenergy, 2002, 22(5); 401-404

7. Ojumu TV, Solomon BO, Betiku E, Layokun SK, Amigun B. Cellulase Production by Aspergillus Flavus Linn Isolate NSPR 101 Fermented in Sawdust, Bagasse and Corncob. African J. of Biotech., 2003, 2(6); 150-152.

8. Giorgio EM, Fonseca MI, Tejerina MR, Ramos-Hryb AB, Sanabria N, Zapata PD, Villalba LD. Chips and Sawdust Substrates Aplication for Lignocellulolytic Enzymes Production by Solid State Fermentation. Int. Res. J. of Biotech., 2012, 3(7); 120-127.

9. Chinedu NS, Nwinyi OC, Okochi VI. Growth and Cellulase Activity of Wild-Type Aspergillus Niger
ANL301 in Different Carbon Sources. Canadian J. Pure and Appl. Sci., 2008, 2(2); 357-362.

10. Farris JL, Grudzein SE, Belanger DS, Cherrry J, Cairns Jr. J. Molluscan Cellulolytis Activity Responses to Zinc Exposure in Laboratory and Field Stream Comparisons. Hydrobiologia, 1994, 287; 161-178.

11. Siregar SH. Isolasi Enzim Selulase dari Pankreas Keong Mas. Jurnal Photon, 2009, 1(2).

12. Maisaroh. Hidrolisis Selulosa Bagas dengan Enzim Selulase dari Bekicot Achatina fulica untuk Produksi Etanol dengan Zymonas mobilis A3. Tesis. Surabaya: Institut Teknologi Sepuluh November, 2009.

13. Masfufatun. Hidrolisis Selulosa Carboxy Methil Cellulose dengan Enzim Selulase dari Bekicot Achatina fulica untuk Produksi Etanol dengan Zymonas mobilis Tesis. Surabaya: Institut Teknologi Sepuluh November, 2010.

14. Li Y., Min Q., Ding M.\& Zhao, F. (2009). Purification, Characterization and Molecular Cloning of a Novel Endo$\beta$-1,4-glucanase AC-EG65 from the Mollusc Ampullariacrossean. Comp. Biochem. Physiol. B. Biochem. Mol. Biol., 2009 153(2); 149-56. doi: 10.1016/j.cbpb.2009.02.011.

15. Fagbohunka BS, Agboola FK, Afolayan A. Characterization of Cellulase from the haemolymph of the giant African snail (Archactina marginata). African J. of Biotech., 2012, 11(38); 9254-64, 10 May, 2012 DOI: 10.5897/AJB10.2071

16. Koswara W. Penyebaran dan Kelimpahan Beberapa Jenis Keong Gondang (Pila spp.) di Perairan Rawa Pening, Jawa Tengah. Karya Ilmiah. Bogor: Fakultas Perikanan Institut Pertanian Bogor, 1985.

17. Watanabe H, Tokuda G. Review: Animal cellulases, CMLS Cell. Mol Life Sci, 2001, 58; 1167-78.

18. Gunam IBW, Wartini WM, Anggraeni AMD, Suparyana PM. Delignifikasi Ampas Tebu dengan Larutan Natrium Hidroksida Sebelum Proses Sakarifikasi secara Enzimatis Menggunakan Enzim Selulase Kasar dari Aspergillus niger FNU 6018. Teknologi Indonesia LIPI, 2011, 34.

19. Raghavendra B, Havannavar GSG. Pre-treatment of Agroresidues for Release of Maximum Reducing Sugar. Karnataka J. Agric. Sci, 2007, 20(4); 771-772.

20. Datta R. Acidogenic Fermentation of Lignocellulose-acid yield and Conversion of Components. Biotechnology and Bioengineering, 1981, 23; 2167-70.

21. Irfan M. Effect of $\mathrm{NaOH}$ and $\mathrm{H}_{2} \mathrm{O}_{2}$ on Degradation of Saw Dust. Wulfenia Journal, 2013, 1.

22. Kim B, Gulati I, Park J, Shin JS. Pretreatment of Cellulosic Waste Sawdust into Reducing Sugars Using Mercerization and Etherification. BioResources, 2012, 7(4); 5152-66.

23. Kobayashi H, Hatada $Y$, Tsubouchi $T$, Nagahama $T$, Takami H. The Hadal Amphipod Hirondellea gigas Possessing a Unique Cellulase for Digesting Wooden Debris Buried in the Deepest Seafloor. PLoS One., 2012, 7(8). doi: 10.1371/journal.pone.0042727.

24. Maryani D. Optimalisasi Konversi Selulosa Menjadi Glukosa pada Limbah serbuk Kayu Agatis Menggunakan Aktivator $\mathrm{Ca}^{2+}$ terhdap Enzim selulase pada Usus Sapi Skripsi. Makassar: Universitas Hasanuddin, 2006. 